\title{
Expendable Railroad Sleepers, of Modern Fuels for Power Stoker fired Boilers
}

\section{Eugeniusz Orszulik*}

Central Mining Institute, Pl. Gwarków 1, 40-116 Katowice, Poland

\section{Abstract}

The paper presents a concept of producing energy on the basis of modern alternative fuels with the expendable railroad sleepers to be burnt in power stokerfired boilers. The thermal energy contained in water vapour and hot water will be utilized in producing in combination, of electrical energy, and for heating of cubature objects. There have been presented the properties of alternative fuels obtained:

- During the combustion of flammable mixture no I (waste - code 170201 wood - from expendable railroad sleepers with hard coal) met the class 5 (highest) emission value requirements with regard to PN-EN 3035: 2012 standard. Other flammable mixtures, no II and III meet the requirements of class 3 (lowest) value with regard to the PN-EN 303-5 standard. The limit for such a low class was the emission value of dust. The laboratory boiler used for testing was not equipped with a device for the separation of dust. In case of equipping the boiler with dust removal device, satisfactory emission results in accordance with the accepted standards of emissions would be obtained.

- From combustion of flammable mixtures have been qualified for development in land areas at a depth of $0.3-15$ m bgl. (23):

- Group A: (a) Land immovable of the area protected on the basis of the Water Law regulations. (b) Areas subject to protection on the basis of the nature protection regulations, if maintaining the current level of land pollution does not pose a threat to human health or environment - for these areas the concentrations resulting from the actual state maintain standards.

- Group B: Land classified as farming land with the exception of lands under ponds and under ditches, forests as well as lands with a high amount of trees and bushes, wasteland as well as built-up and urbanised land with the exception of industrial, mining and communications areas;

- Group C: Industrial, mining and communications areas for the flammable mixture no III - waste - code 170201 wood - from expendable railroad sleepers with cereal straw. Flammable mixtures: no I - waste - code 170201 wood.

- From railroad sleepers with hard coal and no II - waste - code 170201 wood - from railroad sleepers with lignite, were qualified to apply to land development in the areas of : - Group C: industrial, mining and communications areas, developed at the depth of $0.3-15 \mathrm{bgl}$.

- Using the basic component - wood - from railroad sleepers as composite of alternative fuels will:

- Enable to save primary fuels: hard coal and lignite.

- Not cause the excess of permissible emission standards of dust and gaseous substances to the air.

- Enable the development of slag and ash obtained from the combustion process in groups of lands from: Groups $\mathrm{A}, \mathrm{B}$, and $\mathrm{C}$.

- Using alternative fuel composites in energetics, containing wood - from expendable railroad sleepers will not require construction changes of boilers and will provide the meeting of conditions for thermal conversion of wastes in accordance with the requirements given in the Regulation of the Minister of Economy.

Composites of alternative fuels containing wood - from expendable railroad sleepers will be qualified based on the Minister of Environment Regulation and could be qualified as a part of thermal energy conversion of municipal sewage sludge.

Keywords: Wood; Railroad sleepers; Fuel; Combustion; Boiler; Emission

\section{Introduction}

Due to the continuous increase of the demand for fossil fuels to generate heat and electricity, one should reach for new energy sources [1-10]. Waste - code 170201 wood (from railroad sleepers) constitutes a great nuisance for the environment [11-13]. Known waste wood from railroad sleepers treatment methods do not fully solve the problem of the recovery or disposal. The choice of disposal technology of this type of waste is associated with meeting legal regulations $[3,14-$ 19]. Methods known from the literature [7,20-25] have not developed
*Corresponding author: Eugeniusz Orszulik, Central Mining Institute, pl. Gwarków 1, 40 - 116 Katowice, Poland, Tel:48322592267; E-mail: e.orszulik@ gig.katowice.pl

Received February 17, 2014; Accepted October 24, 2014; Published October 31,2014

Citation: Orszulik E (2014) Expendable Railroad Sleepers, of Modern Fuels for Power Stoker fired Boilers. J Adv Chem Eng 4: 113. doi: 10.4172/20904568.1000113

Copyright: (c) 2014 Orszulik E. This is an open-access article distributed under the terms of the Creative Commons Attribution License, which permits unrestricted use, distribution, and reproduction in any medium, provided the original author and source are credited. 
a way of combustion or co-combustion of from railroad sleepers in stoker-fired boilers .

In the present work, [26] a test has been conducted, based on managing stabilized from railroad sleepers by their thermal disposal in the D10 process [15] by co-combustion with fuels i.e. hard coal. The research was aimed at the possibility of using alternative fuels composites containing wood from railroad sleepers as fuel for energy boilers equipped with stoker burners. Hard coal used in the tests, their extraction and acquisition is dependent on the economic situation $[7,27]$.

\section{Research Methodology}

The assumptions of applying new modern energy fuels for combustion in stoker-fired boilers are:

- Reduction of energy acquisition costs.

- Partial substitution of alternative fuel produced of nonhazardous waste, obtained from expendable railroad sleepers, and unsuitable for further recovery, for such a primary fuel as hard coal.

- Ecological effect relying on reduction of:

- Emission of gas and dust substances into the atmosphere, relative to commonly used coal. Production of modern alternative energy fuels whose quality will be comparable with the hard coal commonly used.

In the test was a used expendable wooden railroad sleeper from refurbished railway. Regulation of the Minister of Environment of 27 September 2001 on Waste Catalogue, Law Journal 01.112.1206 [11] expendable wooden railroad sleepers has code 170201 wood.

The purpose of the research was to determine the thermal properties, the measurements of the emissions of dust and gaseous substances emitted to the atmosphere and pollutants to the ground (waste slag and ash) arising during and after the process of co-combustion of composites of alternative fuels containing waste wood from discarded railway sleepers as a fuel to power boilers. The following flammable mixtures were selected to testing:

- Waste - code 170201 wood (from railroad sleepers) with hard coal.

- Waste - code 170201 wood (from railroad sleepers) with lignite.

- Waste - code 170201 wood (from railroad sleepers) with wood chips.

- Waste - code 170201 wood (from railroad sleepers) with cereal straw.

Measurements and tests were carried out in accordance with regulations in force $[1,2,28-30]$. The scope of the study included the following measurements:

Tests and measurements were carried out on a test post, which was equipped with a $25 \mathrm{~kW}$ laboratory water boiler. The boiler was equipped with a mechanical fuel feeder, which was directly connected with a dust burner. The test post was equipped with measuring and control apparatus for continuous and periodic measurement:

- Of the temperature of the water supplying the boiler.

- Of the temperature of the water coming back from the boiler.
- Of water pressure in the boiler.

- Of the flow of water through the boiler.

- Of exhaust gas analysis i.e. $\mathrm{O}_{2}, \mathrm{CO}_{2}, \mathrm{CO}, \mathrm{NO}_{2}, \mathrm{SO}_{2}$.

- Of the analysis of the associated organic carbon content.

- Of the analysis of the content of hydrogen fluoride and hydrogen chloride.

- Of the concentration of dust in exhaust gas.

- Of polluting substances emitted to the ground in order to determine the applicability of the products of combustion in the form of slag and ash into a group of types of land which could be developed [31].

The boiler had a feeder for flammable mixture, the PID controller to control the work of the boiler from heating water temperature in the system.

At the time of tests, the control of combustion process of flammable mixtures and heat generation was based primarily on the maintenance of thermodynamic parameters through adequate air supply to the combustion and the analysis of the composition of the exhaust gas leaving the combustion chamber of the boiler for a specified boiler load. Figure 1 shows the layout of the measuring and control system of the test post.

\section{Flammable mixtures used in testing}

The composition of flammable mixtures was determined on the basis of the obtained research of energy properties of fuels, biomass and waste:

- Hard coal - sortment's sortment coal fine MII.

- Lignite - sortment's sortment coal fine II.

- Cereal straw (biomass).

- Waste - code 170201 wood (from expendable railroad sleepers) after drying.

Properties of used fuels, biomass and wood (from railroad sleepers) after drying as ingredients of flammable mixtures for thermal and environmental testing were presented in Table 1 [32-36].

The composition of flammable mixtures was determined on the basis of the obtained research of energy properties of fuels, biomass and waste:

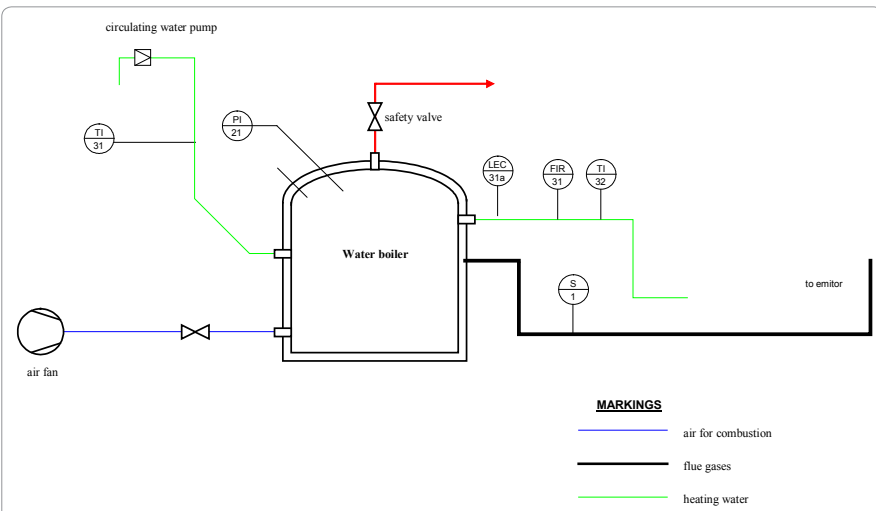

Figure 1: The post for testing the water boiler during the combustion of flammable mixtures. 


\begin{tabular}{|c|c|c|c|c|c|c|}
\hline \multirow[b]{2}{*}{ Number } & \multirow[b]{2}{*}{ Specification } & \multirow[b]{2}{*}{ Unit } & \multicolumn{4}{|c|}{ Fuel } \\
\hline & & & $\begin{array}{l}\text { Hard } \\
\text { coal }\end{array}$ & Lignite & $\begin{array}{l}\text { Cereal } \\
\text { straw }\end{array}$ & $\begin{array}{l}\text { Waste-code } 1702 \\
01 \text { wood }\end{array}$ \\
\hline 1 & Calorif & $\mathrm{kJ} / \mathrm{kg}$ & 22033 & 8133 & 13218 & 13860 \\
\hline 2 & Sulph & $\%$ & 1. & & & \\
\hline 3 & Ash content ${ }^{3 l}$ & $\%$ & 7.21 & 11.07 & 6.55 & 2.65 \\
\hline 4 & Moisture Content ${ }^{4 /}$ & $\%$ & 20.22 & 52.16 & 19.86 & 31.18 \\
\hline 5 & Chlorine Content ${ }^{5 /}$ & $\%$ & 0.095 & 0.046 & 0.254 & 0.10 \\
\hline
\end{tabular}

The method to determine:

1/PN - ISO 1928 - Solid mineral fuels - Determination of gross calorific value by the calorimetric method, and calculation of net calorific value.

2/PN - ISO 334 - Solid mineral fuels - Determination of total sulphur - Eschka method.

3/PN-ISO 1171:2002: "Solid mineral fuels - Determination of ash.

4/PN-80/G-04511: "Solid fuels. Determination of moisture.

5/PN - ISO 587 - Solid mineral fuels - Determination of total chlorine using

Eschka mixture.

Table 1: Properties of used fuels for thermal and environmental tests.

- Hard coal - sortment's sortment coal fine MII.

- Waste - code 170201 wood - from railroad sleepers.

- Lignite had the highest moisture content (52.16\%) and the lowest cereal straw (19.86\%).

- Cereal straw had the highest chlorine content (0.254\%), and the lowest wood chips $(0.10 \%)$.

Waste - code 170201 wood - from expendable railroad sleepers were characterized by the calorific value of $13860 \mathrm{~kJ} / \mathrm{kg}$, which was higher than the limit set out in the Regulation of the Minister of Economy [18]. For this reason, the waste should not be stored at dumping site.

The composition of flammable mixtures was determined after the established criteria:

- The average calorific value should amount to minimum 8.0 MJ/ $\mathrm{kg}$.

- Sulphur content should amount to $0.6 \%$.

- Ash content should amount to $15 \%$.

- Chlorine content should amount to 5\%.

- Moisture content should amount to $20 \%$.

The criteria were established on the basis of the coals currently used for power generation and heating, mostly lignite in dust boilers.

Table 2 presents the results obtained on the basis of the results of the tests of fuels, biomass and wood - from expendable railroad sleepers compositions of flammable mixtures, and in Table 3 are presented the properties of flammable mixtures used for thermal and environmental tests.

Flammable mixtures: No I, II and III meet the established criteria.

The best energy properties have the flammable mixture No I - waste - 170201 wood - from expendable railroad sleepers with hard coal. The mixture has a high calorific value $(20094 \mathrm{~kJ} / \mathrm{kg})$, low ash content of $12.50 \%$, but contains a high sulphur content of $0.9 \%$.

The worst energy properties have the flammable mixture No II - waste - 170201 wood - from expendable railroad sleepers with lignite. It has a very low calorific value $(8112 \mathrm{~kJ} / \mathrm{kg})$, low ash content of $13.55 \%$ and sulphur of $0.43 \%$ and a high moisture content of $46.71 \%$. Properties of the mixture No II are comparable to lignite burned in
BOT power plants.

Chlorine content in flammable mixtures No I, II and III is very low, which will require the maintenance of the combustion process to ensure the temperature of exhaust gases above $850^{\circ} \mathrm{C}$ for at least 2 seconds $[4,37]$.

\section{Determining the energy efficiency of the boiler during the combustion of flammable mixtures}

Boiler energy efficiency [38] at the time of the combustion of flammable mixtures was determined by definition for the tested combustible mixture, taking into account the supplied energy flow as the chemical energy contained in the mixture:

$$
\eta=\frac{Q_{N}}{Q_{z}}
$$

Where: $\mathrm{Q}_{\mathrm{N}}$ - flow of the energy brought out, $\mathrm{kW}, \mathrm{Q}_{\mathrm{z}}$ - flow of supplied energy, $\mathrm{kW}$.

Boiler efficiency determined by the formula [a] refers to a specific point of the boiler heat load (at the moment of measurement). Stream energy brought out from water boiler:

$Q_{N}=\stackrel{0}{m}\left(h_{2}-h_{1}\right)$

Where: $Q_{N}$ - determined thermal useful power, $\mathrm{kW}$

$m$ - Hot-water mass flow, $\mathrm{kg} / \mathrm{s}$

$h_{2}$ - Enthalpy of water at an average temperature of outflow, $t_{2}$ , $\mathrm{kJ} / \mathrm{kg}$

$h_{1}$ - Enthalpy of water at an average temperature on inflow, $t_{1}$ , $\mathrm{kJ} / \mathrm{kg}$

The stream of energy supplied to the boiler:

$Q_{Z}={ }^{0} m\left[\left(H_{(N)}+h_{F}\right) /\left(1-l_{u}\right)+J_{(N) A}\right]$

Where - flow of supplied energy, $\mathrm{kW}$

${ }_{m}^{0}$ - Flow of fuel mass, $\mathrm{kg} / \mathrm{s}$

$\mathrm{kg}$

$H_{(N)}$ - The calorific value of fuel at reference temperature, $t_{r}, \mathrm{~kJ} /$

$h_{F}$ - Fuel enthalpy $h_{F}=c_{F}\left(t_{F}-t_{r}\right), \mathrm{kJ} / \mathrm{kg}$

$c_{F}$ - Proper heat capacity of fuel, $\mathrm{kJ} / \mathrm{kgK}$

$t_{F}$ - Fuel temperature, ${ }^{\circ} \mathrm{C}$

$t_{r}$ - Reference temperature, ${ }^{\circ} \mathrm{C}$

\begin{tabular}{|l|c|c|}
\hline Mixture & Fuel & Waste-code 170201 wood \\
\hline No I & Hard coal- $80 \%$ of the mass & $20 \%$ of the mass \\
\hline No II & Lignite- $20 \%$ of the mass & $80 \%$ of the mass \\
\hline No III & Cereal straw-50\% of the mass & $50 \%$ of the mass \\
\hline
\end{tabular}

Table 2: The composition of the flammable mixtures for thermal andenvironmental tests.

\begin{tabular}{|l|l|c|c|c|c|}
\hline \multirow{2}{*}{ Number } & \multirow{2}{*}{ Specification } & \multirow{2}{*}{ Unit } & \multicolumn{3}{|c|}{ Flammable mixture } \\
\cline { 3 - 6 } & & & No I & No II & No III \\
\hline 1 & Calorific value & $\mathrm{kJ} / \mathrm{kg}$ & 20094 & 8112 & 13315 \\
2 & Sulphur content & $\%$ & 0.90 & 0.62 & 0.43 \\
3 & Ash content & $\%$ & 12.50 & 14.74 & 13.55 \\
4 & Moisture content & $\%$ & 21.02 & 46.71 & 25.64 \\
5 & Chlorine content & $\%$ & 0.070 & 0.049 & 0.018 \\
\hline
\end{tabular}

Table 3: Properties of the flammable mixtures for thermal and environmental testing. 
$l_{u}$ - Non-burnt fuel flow mass to flow of supplied fuel mass ratio $l_{u}=m_{F u} / m_{F o}$

$$
J_{(N) A} \text {-Enthalpyof combustion air } J_{(N) A}=\mu_{A} C_{p A}\left(t_{A}-t_{r}\right)
$$

, $\mathrm{kJ} / \mathrm{kg}$

$C_{p A}$ - Proper heat capacity of air, $\mathrm{kJ} /(\mathrm{kgK})$

$\mu_{A}$ - Air mass to fuel mass ratio

$t_{A}$ - Air temperature at the border of the balance cover, ${ }^{\circ} \mathrm{C}$

Study of solid products - Slag and ash obtained after combustion of flammable mixtures

Solid waste obtained after combustion of flammable mixtures - slag and ash - have undergone the tests of the chemical composition for the content of trace elements. Marked quantities of heavy metals in the analysed samples were compared to the standards of the quality of the soil or land contained in the Regulation of the Minister of Environment [2] with regard to (current and planned land development) groups of types of land where they can be used.

\section{The Results of the Tests and Measurements from Co- Combustion of Flammable Mixtures}

\section{Combustion of the flammable mixture no I}

Study of the combustion of flammable mixture no I - wood - from expendable railroad sleepers with hard coal has been carried out for a heat load laboratory boiler of $85 \pm 5 \%$.

Thermal-emission tests were aimed at determining the energy efficiency of the boiler and the designation of emission values occurring during the combustion of flammable mixtures no I. Thermal-emission test results for the flammable mixture no I are presented in Table 4.

Thermal and emission values of the boiler obtained during combustion of flammable mixture no I were compared with the limit emission values contained in standard PN-EN 303-5: 2012 [1] (Table 5):

Emission values obtained during the tests of the combustion of flammable mixture no I (waste - code 170201 wood - From expendable railroad sleepers with hard coal) meet the class 5 (highest) emission value requirements with regard to PN-EN 303-5: 2012 standard [1].

Solid product tests - slag and ash - obtained from the combustion process of the flammable mixture number I were aimed at designation of factors qualifying its choice for use as a raw material useful in the construction industry or farming.

Table 6 shows the comparison of the concentrations of trace elements obtained in testing. Obtained concentrations were compared to the standards of the quality of the soil or land contained in the Regulation of the Minister of Environment [2].

Test results presented in table 6 for the tested sample of the waste - slag and ash obtained after the combustion of flammable mixture no I, contain values higher than the limit values for soil and land quality standards with regard to surface land assigned to group A and B [2]. The sample meets the requirements of land development in areas of Group C - industrial, mining and communication areas, developed at a depth of $0.3-15 \mathrm{~m}$ bgl. [2].

\section{Test of combustion of flammable mixture no II}

Testing the combustion of flammable mixture no II - 170201 wood - from expendable railroad sleepers with lignite has been carried out for a heat load laboratory boiler of $85 \pm 5 \%$.

Thermal-emission tests were aimed at determining the energy efficiency of the boiler and the designation of emission values occurring during the combustion of flammable mixture no II. Thermal-emission test results of the flammable mixture no II were shown in table 7.

At the time of the thermal - emission test the following values were obtained (table 8 ):

Thermal and emission values of the boiler obtained during combustion of flammable mixture no II were compared with the limit emission values contained in standard PN-EN 303-5: 2012 [1] (table 9):

Emission values obtained during the tests of the combustion of flammable mixture no II (waste - code 170201 wood - from expendable railroad sleepers with lignite) meet the class 3 (lowest) emission value requirements with regard to PN-EN 303-5: 2012 standard [1].

Solid product tests - slag and ash - obtained from the combustion process of the flammable mixture no II were aimed at the designation of factors qualifying its choice for use as a raw material useful in the construction industry or farming. Table 10 provides a comparison of the concentration values of trace elements in combustion tests of the flammable mixture no II with the standards of the soil or land quality contained in the Regulation of the Minister of Environment [2].

Test results presented in table 10 for the tested sample of the waste - slag and ash obtained after the combustion of flammable mixture no II, contain values higher than the limit values for soil and land quality standards with regard to surface land assigned to group A and B [2]. The tested sample meets the requirements of land development in areas of Group C - industrial, mining and communication areas, developed at a depth of 0.3-15 $\mathrm{m}$ bgl. [2].

\section{Test of combustion of flammable mixture no III}

Testing the combustion of flammable mixture no III - 170201 wood - from expendable railroad sleepers with cereal straw has been carried out for a heat load laboratory boiler of $85 \pm 5 \%$.

Thermal - emission tests were aimed at determining the energy efficiency of the boiler and the designation of emission values occurring during the combustion of flammable mixtures no III.

Thermal - emission test results of the flammable mixture no III were shown in table 11.

At the time of the thermal-emission study the following values were obtained (Table 12):

Thermal and emission values of the boiler obtained during combustion of flammable mixture no III were compared with the limit emission values contained in standard PN-EN 303-5: 2012 [1] (Table 13):

Emission values obtained during the tests of the combustion of flammable mixture no III (waste - code 170201 wood - from expendable railroad sleepers with cereal straw) meet the class 3 (lowest) emission value requirements with regard to PN-EN 303-5: 2012 standard [1].

Table 14 provides a comparison of the concentration values of trace elements in the solid product - slag and ash - obtained in combustion tests of the flammable mixture no III with the standards of the soil or land quality contained in the Regulation of the Minister 
Citation: Orszulik E (2014) Expendable Railroad Sleepers, of Modern Fuels for Power Stoker fired Boilers. J Adv Chem Eng 4: 113. doi: 10.4172/20904568.1000113

Page 5 of 8

\begin{tabular}{|c|c|c|c|c|c|c|c|c|c|c|c|c|}
\hline \multicolumn{3}{|c|}{ Water temperature, ${ }^{\circ} \mathrm{C}$} & \multirow{2}{*}{$\begin{array}{l}\text { Water flow, } \\
\mathrm{kg} / \mathrm{h} \text {. }\end{array}$} & \multirow{2}{*}{\multicolumn{2}{|c|}{$\begin{array}{l}\text { Amount of gener- } \\
\text { ated energy, } \\
\text { kW }\end{array}$}} & \multirow{2}{*}{\multicolumn{2}{|c|}{$\begin{array}{l}\text { Water pressure } \\
\text { in the boiler, } \\
\text { bar }\end{array}$}} & \multirow{2}{*}{\multicolumn{2}{|c|}{$\begin{array}{l}\text { Amount of con- } \\
\text { sumed fuel, } \mathrm{kg} / \mathrm{h}\end{array}$}} & \multirow{2}{*}{$\begin{array}{l}\text { Coefficient of air } \\
\text { excess, } \\
\lambda\end{array}$} & \multirow{2}{*}{$\begin{array}{l}\text { Boiler } \\
\text { load } \\
\%\end{array}$} & \multirow{2}{*}{$\begin{array}{l}\text { Boiler efficiency } \\
\%\end{array}$} \\
\hline Supply & & & & $\begin{array}{l}\text { ate } \\
\text { kW }\end{array}$ & & & & & & & & \\
\hline 46.70 & \multicolumn{2}{|c|}{65.45} & \multicolumn{2}{|c|}{21.51} & 0.5 & 0.1 & & & 0.15 & 1.38 & 86 & 79.65 \\
\hline \multicolumn{13}{|c|}{ Content of combustible parts in ash and slag: $42.09 \%$} \\
\hline \multicolumn{2}{|l|}{ Unit } & $\begin{array}{l}\mathbf{O}_{2} \\
\%\end{array}$ & $\begin{array}{l}\mathrm{CO}_{2} \\
\%\end{array}$ & $\mathrm{SO}_{2}^{* \prime}$ & $\mathrm{NO}_{2}^{*}$ & $\mathrm{CO}^{*}$ & \multicolumn{2}{|c|}{ Dust $*$} & OGC $^{*}$ & $\mathrm{HCl}$ & \multirow[t]{2}{*}{ HF } & \\
\hline \multicolumn{2}{|c|}{$\mathrm{mg} / \mathrm{m}^{3}$} & 11.3 & 9.5 & 1105.7 & 146.3 & 457 & \multirow{2}{*}{\multicolumn{2}{|c|}{$\begin{array}{c}30 \\
0.003\end{array}$}} & 0.15 & 13 & & p.o. \\
\hline \multicolumn{2}{|c|}{$\mathrm{kg} / \mathrm{h}$} & & & 0.012 & 0.002 & 0.005 & & & 0.00000 & 0.00014 & \multicolumn{2}{|r|}{ p.o. } \\
\hline
\end{tabular}

"- by the oxygen content of $10 \%$ in the exhaust gas in the contractual conditions at a temperature of $273 \mathrm{~K}$ and a pressure of $101.3 \mathrm{kPa}$

Table 4: Thermal-emission test results obtained during combustion of flammable mixtures no I.

\begin{tabular}{|c|c|c|c|c|c|}
\hline Specification & \multirow{2}{*}{$\begin{array}{l}\text { Unit } \\
\%\end{array}$} & \multirow{2}{*}{$\begin{array}{l}\text { Result } \\
81\end{array}$} & \multicolumn{3}{|c|}{$\begin{array}{l}\text { Limit values in accordance with } \\
\text { PN-EN 303-5 }\end{array}$} \\
\hline Boiler efficiency in accordance with PN-EN 303-5 & & & & & \\
\hline \multirow[b]{3}{*}{$\begin{array}{l}\text { The concentration of dust and gaseous substances emitted into the air: } \\
\text { - Dust } \\
\text { - OGC } \\
\text { - Sulphur dioxide } \\
\text { - Nitrogen dioxide } \\
\text { - Carbon monoxide }\end{array}$} & \multirow[b]{3}{*}{$\begin{array}{l}\mathrm{mg} / \mathrm{m}^{3} \\
\mathrm{mg} / \mathrm{m}^{3} \\
\mathrm{mg} / \mathrm{m}^{3} \\
\mathrm{mg} / \mathrm{m}^{3} \\
\mathrm{mg} / \mathrm{m}^{3}\end{array}$} & \multirow[b]{3}{*}{$\begin{array}{l}30 \\
0.15 \\
1106 \\
146 \\
457\end{array}$} & \multicolumn{3}{|c|}{ Class } \\
\hline & & & 3 & 4 & 5 \\
\hline & & & $\begin{array}{l}150 \\
80 \\
- \\
- \\
3000\end{array}$ & $\begin{array}{c}60 \\
30 \\
- \\
- \\
1000\end{array}$ & $\begin{array}{c}40 \\
20 \\
- \\
- \\
500\end{array}$ \\
\hline
\end{tabular}

Table 5: Thermal and emission values of the boiler obtained during combustion of flammable mixture no I.

\begin{tabular}{|c|c|c|c|c|}
\hline \multirow{5}{*}{ Element } & \multicolumn{3}{|c|}{ Land $^{*}$} & \multirow{4}{*}{$\begin{array}{l}\text { The value determined for the } \\
\text { flammable mixture no I }\end{array}$} \\
\hline & Group A & Group B & Group C & \\
\hline & \multicolumn{3}{|c|}{ Depth in $\mathrm{m}$ bgl } & \\
\hline & & $0-0.3$ & $0-2.0$ & \\
\hline & \multicolumn{4}{|c|}{ mg/kg s.m. } \\
\hline \multicolumn{5}{|c|}{ I Metals } \\
\hline Arsenic As & 20 & 20 & 60 & $<2$ \\
\hline Barium $\mathrm{Ba}$ & 200 & 200 & 1000 & 692 \\
\hline Cadmium Cd & 1 & 4 & 15 & $<2$ \\
\hline Cobalt Co & 20 & 20 & 200 & 6 \\
\hline Chrome $\mathrm{Cr}$ & 50 & 150 & 500 & 35 \\
\hline Copper Cu & 30 & 150 & 600 & 26 \\
\hline Molybdenum Mo & 10. & 10 & 250 & $<2$ \\
\hline Nickel Ni & 35 & 100 & 300 & 24 \\
\hline Lead Pb & 50 & 100 & 600 & 29 \\
\hline Tin, Sn & 20 & 20 & 350 & 2 \\
\hline Zinc Zn & 100 & 300 & 1000 & 92 \\
\hline
\end{tabular}

"By the Regulation of the Minister of Environment.

Table 6: Limit values for concentrations in the soil or land, compared with the results obtained from the analyses of the test sample of the solid product-ash and slag-from combustion of the flammable mixture no 1 .

\begin{tabular}{|c|c|c|c|c|c|c|c|c|}
\hline \multicolumn{2}{|c|}{ Water temperature, ${ }^{\circ} \mathrm{C}$} & \multirow[b]{2}{*}{ Water flow, kg/h } & \multirow{2}{*}{$\begin{array}{l}\text { Amount of } \\
\text { generated energy, } \\
\text { kW }\end{array}$} & \multirow{2}{*}{$\begin{array}{l}\text { Water } \\
\text { pressure in } \\
\text { the boiler, bar }\end{array}$} & \multirow{2}{*}{$\begin{array}{l}\text { Amount of } \\
\text { consumed fuel, } \\
\mathrm{kg} / \mathrm{h}\end{array}$} & \multirow{2}{*}{$\begin{array}{l}\text { Coefficient of air } \\
\text { excess, } \\
\lambda\end{array}$} & \multirow{2}{*}{$\begin{array}{l}\text { Boiler load } \\
\%\end{array}$} & \multirow{2}{*}{$\begin{array}{l}\text { Boiler efficiency } \\
\%\end{array}$} \\
\hline Supply & Return & & & & & & & \\
\hline 43.70 & 61.48 & 43.06 & 1.01 & 0.1 & 0.45 & 1.33 & 80 & 62.22 \\
\hline
\end{tabular}

Content of combustible parts in ash and slag, $\% \quad 42.09 \%$

Table 7: Thermal-emission test results obtained during combustion of flammable mixture no II.

\begin{tabular}{|c|c|c|c|c|c|c|c|c|c|}
\hline Unit & $\begin{array}{l}\mathrm{O}_{2} \\
\%\end{array}$ & $\mathrm{CO}_{\%}$ & $\mathrm{SO}_{2}^{* /}$ & $\mathrm{NO}_{2}{ }^{*}$ & $\mathrm{CO}^{*}$ & Dust ${ }^{*}$ & OGC $^{*}$ & $\mathrm{HCl}$ & HF \\
\hline $\mathrm{mg} / \mathrm{m}^{3}$ & 13.0 & 7.8 & 211.8 & 134.8 & 1098.6 & 122 & 0.89 & 8 & p.o. \\
\hline kg/h & & & 0.002 & 0.001 & 0.010 & 0.003 & 0.00014 & 0.00008 & p.o. \\
\hline
\end{tabular}

${ }^{*} \mathrm{By}$ the oxygen content of $10 \%$ in the exhaust gas in the contractual conditions at a temperature of $273 \mathrm{~K}$ and a pressure of $101.3 \mathrm{kPa}$.

Table 8: Thermal-emission test results 
Citation: Orszulik E (2014) Expendable Railroad Sleepers, of Modern Fuels for Power Stoker fired Boilers. J Adv Chem Eng 4: 113. doi: 10.4172/20904568.1000113

Page 6 of 8

\begin{tabular}{|c|c|c|c|c|c|}
\hline Specification & Unit & Result & \multicolumn{3}{|c|}{$\begin{array}{l}\text { Limit values in accordance with } \\
\text { PN-EN 303-5 }\end{array}$} \\
\hline Boiler efficiency in accordance with PN-EN 303-5 & $\%$ & \multicolumn{4}{|c|}{62} \\
\hline \multirow[b]{3}{*}{$\begin{array}{l}\text { The concentration of dust and gaseous substances emitted into the air: } \\
\text { - Dust } \\
\text { - OGC } \\
\text { - Sulphur dioxide } \\
\text { - Nitrogen dioxide } \\
\text { - Carbon monoxide }\end{array}$} & & & \multicolumn{3}{|c|}{ Class } \\
\hline & & & 3 & 4 & 5 \\
\hline & $\begin{array}{l}\mathrm{mg} / \mathrm{m}^{3} \\
\mathrm{mg} / \mathrm{m}^{3} \\
\mathrm{mg} / \mathrm{m}^{3} \\
\mathrm{mg} / \mathrm{m}^{3} \\
\mathrm{mg} / \mathrm{m}^{3}\end{array}$ & $\begin{array}{c}122 \\
1 \\
212 \\
135 \\
1099\end{array}$ & $\begin{array}{c}150 \\
80 \\
- \\
- \\
3000\end{array}$ & $\begin{array}{c}60 \\
30 \\
- \\
- \\
1000\end{array}$ & $\begin{array}{c}40 \\
20 \\
- \\
- \\
500\end{array}$ \\
\hline
\end{tabular}

Table 9: Thermal and emission values of the boiler obtained during combustion of flammable mixture no II.

\begin{tabular}{|c|c|c|c|c|}
\hline \multirow{5}{*}{ Element } & \multicolumn{3}{|c|}{ Land $^{\prime *}$} & \multirow{4}{*}{$\begin{array}{l}\text { The value determined for } \\
\text { sample: } \\
\text { Flammable mixture no II }\end{array}$} \\
\hline & Group A & Group B & Group C & \\
\hline & \multicolumn{3}{|c|}{ Depth in $\mathrm{m}$ bgl } & \\
\hline & & $0-0.3$ & $0-2.0$ & \\
\hline & \multicolumn{4}{|c|}{ mg/kg s.m. } \\
\hline \multicolumn{5}{|c|}{ I Metals } \\
\hline Arsenic As & 20 & 20 & 60 & $<2$ \\
\hline Barium Ba & 200 & 200 & 1000 & 5 \\
\hline Cadmium Cd & 1 & 4 & 15 & 194 \\
\hline Cobalt Co & 20 & 20 & 200 & $<2$ \\
\hline Chrome $\mathrm{Cr}$ & 50 & 150 & 500 & 11 \\
\hline Copper Cu & 30 & 150 & 600 & 53 \\
\hline Molybdenum Mo & 10 & 10 & 250 & 19 \\
\hline Nickel Ni & 35 & 100 & 300 & 85 \\
\hline Lead $\mathrm{Pb}$ & 50 & 100 & 600 & $<2$ \\
\hline Tin, Sn & 20 & 20 & 350 & 37 \\
\hline Zinc Zn & 100 & 300 & 1000 & 29 \\
\hline
\end{tabular}

"by the Regulation of the Minister of Environment dated 9 September 2002 on the soil and ground quality standards - Dz. U. 02.165.1358 (Journal of Laws 02.165.1358). Table 10: Limit values for concentrations in the soil or land, compared with the results obtained from the analysis of the test sample of the solid product-ash and slagfrom combustion of the flammable mixture no II.

\begin{tabular}{|c|c|c|c|c|c|c|c|c|}
\hline \multicolumn{2}{|c|}{ Water temperature, ${ }^{\circ} \mathrm{C}$} & \multirow[b]{2}{*}{ Water flow, kg/h } & \multirow{2}{*}{$\begin{array}{l}\text { Amount of } \\
\text { generated energy, } \\
\text { kW }\end{array}$} & \multirow{2}{*}{$\begin{array}{l}\text { Water } \\
\text { pressure in } \\
\text { the boiler, bar }\end{array}$} & \multirow{2}{*}{$\begin{array}{l}\text { Amount of } \\
\text { consumed fuel, } \\
\mathrm{kg} / \mathrm{h}\end{array}$} & \multirow{2}{*}{$\begin{array}{l}\text { Coefficient of air } \\
\text { excess, } \\
\lambda\end{array}$} & \multirow[b]{2}{*}{$\begin{array}{l}\text { Boiler load } \\
\%\end{array}$} & \multirow[b]{2}{*}{$\begin{array}{l}\text { Boiler efficiency } \\
\%\end{array}$} \\
\hline Supply & Return & & & & & & & \\
\hline 45.12 & 63.12 & 14.56 & 0.33 & 0.1 & 0.16 & 1.25 & 83 & 61.8 \\
\hline
\end{tabular}

Table 11: Thermal-emission test results obtained during combustion of flammable mixture no III.

\begin{tabular}{|c|c|c|c|c|c|c|c|c|c|}
\hline Unit & $\begin{array}{l}\mathrm{O}_{2} \\
\%\end{array}$ & $\underset{\%}{\mathrm{CO}_{2}}$ & $\mathrm{SO}_{2}^{* \prime}$ & $\mathrm{NO}_{2}^{*}$ & $\mathrm{CO}^{*}$ & Dust * ${ }^{*}$ & OGC $^{* /}$ & $\mathrm{HCl}$ & HF \\
\hline $\mathrm{mg} / \mathrm{m}^{3}$ & 12.8 & 7.6 & 637 & 217 & 966 & 565 & 2.5 & 3 & p.o. \\
\hline $\mathrm{kg} / \mathrm{h}$ & & & 0.002 & 0.001 & 0.010 & 0.003 & 0.00000 & 0.00005 & p.o. \\
\hline
\end{tabular}

${ }^{*} \mathrm{By}$ the oxygen content of $10 \%$ in the exhaust gas in the contractual conditions at a temperature of $273 \mathrm{~K}$ and a pressure of $101.3 \mathrm{kPa}$.

Table 12: Thermal-emission study results.

\begin{tabular}{|c|c|c|c|c|c|}
\hline Specification & Unit & Result & \multicolumn{3}{|c|}{$\begin{array}{l}\text { Limit values in accordance with } \\
\text { PN-EN 303-5 }\end{array}$} \\
\hline Boiler efficiency in accordance with PN-EN 303-5 & $\%$ & \multicolumn{4}{|c|}{62} \\
\hline \multirow[b]{3}{*}{$\begin{array}{l}\text { The concentration of dust and gaseous subst } \\
\text { - Dust } \\
\text { - OGC } \\
\text { - Sulphur dioxide } \\
\text { - Nitrogen dioxide } \\
\text { - Carbon monoxide }\end{array}$} & & & \multicolumn{3}{|c|}{ Class } \\
\hline & & & 3 & 4 & 5 \\
\hline & $\begin{array}{l}\mathrm{mg} / \mathrm{m}^{3} \\
\mathrm{mg} / \mathrm{m}^{3} \\
\mathrm{mg} / \mathrm{m}^{3} \\
\mathrm{mg} / \mathrm{m}^{3} \\
\mathrm{mg} / \mathrm{m}^{3}\end{array}$ & $\begin{array}{c}565 \\
3 \\
637 \\
217 \\
966\end{array}$ & $\begin{array}{c}150 \\
80 \\
- \\
- \\
3000\end{array}$ & $\begin{array}{c}60 \\
30 \\
- \\
- \\
1000\end{array}$ & $\begin{array}{c}40 \\
20 \\
- \\
- \\
500\end{array}$ \\
\hline
\end{tabular}

Table 13: Emission values obtained during the tests of the combustion of flammable mixture no III. 


\begin{tabular}{|c|c|c|c|c|}
\hline \multirow{5}{*}{ Element } & \multicolumn{3}{|c|}{ Land $^{*}$} & \multirow{4}{*}{$\begin{array}{l}\text { The value determined for } \\
\text { Sample: } \\
\text { Flammable mixture no III }\end{array}$} \\
\hline & Group A & Group B & Group C & \\
\hline & \multicolumn{3}{|c|}{ Depth in $\mathrm{m}$ bgl } & \\
\hline & & $0-0.3$ & $0-2.0$ & \\
\hline & \multicolumn{4}{|c|}{ mg/kg s.m. } \\
\hline \multicolumn{5}{|c|}{ I Metals } \\
\hline Arsenic As & 20 & 20 & 60 & $<0.19$ \\
\hline Barium Ba & 200 & 200 & 1000 & $<0.19$ \\
\hline Cadmium Cd & 1 & 4 & 15 & $<0.047$ \\
\hline Cobalt Co & 20 & 20 & 200 & $<0.19$ \\
\hline Chrome Cr & 50 & 150 & 500 & $<0.19$ \\
\hline Copper Cu & 30 & 150 & 600 & $<0.19$ \\
\hline Molybdenum Mo & 10 & 10 & 250 & 0.37 \\
\hline Nickel Ni & 35 & 100 & 300 & $<0.47$ \\
\hline Lead $\mathrm{Pb}$ & 50 & 100 & 600 & $<0.47$ \\
\hline Tin, Sn & 20 & 20 & 350 & $<0.19$ \\
\hline Zinc Zn & 100 & 300 & 1000 & $<0.19$ \\
\hline
\end{tabular}

"by the Regulation of the Minister of Environment dated 9 September 2002 on the soil and land quality standards - Dz. U. 02.165.1358 (Journal of Laws 02.165 .1358 ). Table 14: Limit values for concentrations in the soil or land, compared with the results obtained from the analysis of the test sample of the solid product-ash and slagfrom combustion of the flammable mixture no III.

of Environment [2].

Results of tests contained in Table 9 for the tested sample of waste - slag and ash obtained after combustion of flammable mixture no III - waste - code 170201 wood - from expendable railroad sleepers with cereal straw showed values lower than the limit values for soil and land quality in relation to surface grounds assigned to group A, B and C [2]. The sample meets the requirements for application in development of land:

- Group A: (a) Land immovable of the area protected on the basis of the Water Law regulations. (b) Areas subject to protection on the basis of the nature protection regulations, if maintaining the current level of land pollution does not pose a threat to human health or environment - for these areas the concentrations resulting from the actual state maintain standards.

- Group B: land classified as agricultural land except the land under ponds and ditches, forest land, land with a high amount of woods and bushes, waste land as well as built-up and urbanized land, with the exception of industrial land, mining areas, and communication areas;

- Group C: industrial, mining and communication areas; Developed to a depth of 0.3-15 m bgl. [2].

\section{Summary}

The paper presents a concept of producing energy on the basis of modern alternative fuels with the expendable railroad sleepers to be burnt in power stokerfired boilers. The thermal energy contained in water vapour and hot water will be utilized in producing in combination, of electrical energy, and for heating of cubature objects. There have been presented the properties of alternative fuels obtained, and the concept of their utilization in the process of emissions of natural environment. The paper presents research methodology thermal properties, the measurements of the emissions of dust and gaseous substances emitted to the atmosphere and pollutants to the ground arising during, flammable mixtures used in testing on the basis of the obtained research of energy properties of fuels, biomass and waste and the energy efficiency of the boiler during the combustion of flammable mixtures: hard coal, lignite, cereal straw and waste - wood (from railroad sleepers).

\section{References}

1. PN-EN 303-5 (2012) Heating boilers for solid fuels, hand and automatically stocked, with a nominal heat of up to $500 \mathrm{~kW}$-Terminology, requirements, testing and marking.

2. Regulation of the Minister of Environment (2002) on the soil and land quality standards.

3. Regulation of the Minister of Environment (2011) on standards for emissions from installations-Journal of Laws 11.95.558.

4. Regulation of the Minister of Economy, Labour and Social Policy (2003) amending the regulation concerning the requirements on the process of thermal transformation of waste. Journal of Laws 03.1.2.

5. Regulation of the Minister of Environment (2010) concerning detailed technical conditions of qualifying part of energy recovered from thermal transformation of municipal wastes-Journal of Laws 110.117.788.

6. Regulation of the Minister of Economy (2008) concerning the detailed scope of obligation to obtain and present for the discontinuance of certificate acquaintance of compensatory payment, purchasing electric energy and heat generated from renewal sources and the obligation to confirm the data on the amount of electric energy generated in a renewal energy source-Journal of Laws 08.156.969.

7. Czop M, Kajda-Szcześniak M (2013) Methods of disposal of sewage sludge Archives of Waste Management and Enviromental Protection 15: 83-92.

8. Eduljee G (1994) Organic micro pollutants emissions from waste incineration. In: Hester RE, Harrison RM (ed.)-Waste incineration and the environment, Royal Society of Chemistry, London.

9. Karekez S, Coelhob ST (2004) Renewable energy-traditional biomass vs Modern biomass. Energy Policy 32: 711-714.

10. Demirbas A (2005) Potential applications of renewable energy sources, biomass combustion problems in boiler power systems and combustion related environmental issues. Progress in energy and combustion Science 31: 171 192.

11. Regulation of the Minister of Environment (2001) on waste catalogue-Journal of Laws 01.112.1206.

12. Środa K, Kijo-Kleczkowska A, Otwinowski H (2013) Methods of disposal of sewage sludge. Archives of Waste Management and Environmental Protection 15: $33-50$

13. Środa K, Kijo-Kleczkowska A, Otwinowski H (2012) Thermal disposal of sewage sludge. Inżynieria Ekologiczna 28: 67-81.

14. Law (2001) Environmental Law-Journal of Laws $01.62,627$ consolidated text Journal of Laws 08.25.150 dated 23.01.2008

15. Law (2012) on waste-Journal of Laws 13.21

16. Regulation of the Minister of Environment (2012) on permissible substance 
Citation: Orszulik E (2014) Expendable Railroad Sleepers, of Modern Fuels for Power Stoker fired Boilers. J Adv Chem Eng 4: 113. doi: 10.4172/20904568.1000113

Page 8 of 8

degree in the air-Journal of Laws 12.1031

17. Regulation of the Minister of Environment (2010) on reference values for some substances in the air, Journal of Laws 10.16.87.

18. Regulation of the Minister of Economy and Labour (2005) on criteria and procedures of permissions for waste collection at particular types of landfills, Journal of Laws 05.186.1553.

19. Regulation of the Minister of Environment (2002) on the soil and land quality standards, Journal of Laws 02.165.1358.

20. Fieducik J, Gawroński (2010) A Sewage sludge drying and combustion as a method of its utilization based on the example of incineration plant in Olsztyn. Zeszyty Naukowe Politechniki Rzeszowskiej. Budownictwo i Inżynieria Środowiska 57: 147-154.

21. Girczys J, Rećko K (2001) The possibilities of mutual management of sewage sludge and waste coal slime. Inżynieria i Ochrona Środowiska 4: 107-116.

22. Pajak T (2003) Combustion and co-combustion of sewage sludge-basic determinants. Przegląd Komunalny 1: 35-38.

23. Pajak T, Wielgosiński G (2003) Contemporary technologies of sewage sludge drying and combustion-criteria and determinants of technology choice. II Międzynarodowa i XIII Krajowa Konferencja Naukowo-Techniczna n.t. Nowe spojrzenia na osady ściekowe. Odnawialne źródła energy i Częstochowa 491-500.

24. Wandrasz JW, Kozioł M, Landrat M, Ścierski W, Wandrasz AJ (2000) Possibility of sludge co-combustion from sewage-treatment plants jointly with coal in stoker boilers. Gospodarka Paliwami i Energia 8: 10-15

25. Wielgosiński G (2002) Combustion, co-combustion and drying of sewage sludge. Przegląd Komunalny 1:10-15.

26. GIG documentation of research and development work- No 5820777 3-323.
27. Ochrona Środowiska 2000-2010. Główny Urzą Statystyczny. Informacje i Opracowania Statystyczne. Warszawa 2010.

28. Regulation of the Minister of Economy and Labour (2005) on criteria and procedures of permissions for waste collection at particular types of landfills, Journal of Laws 05.186 .1553$.

29. Regulation of the Minister of Environment (2008) on requirements concerning measurements on volume of emission and collected water-Journal of Laws 08.206.1291.

30. PN-Z-04030-7 (1994) Measurement of dust concentration and flow in waste gases using the gravimetric method. Flow, gas physical parametres, dust emission measurements.

31. Regulation of the Minister of Environment (2008) on types of results of measurements carried out because of installation or device exploitation as well as other data terms and ways of their presentation. Journal of Laws.08.215.1366

32. PN-ISO 1928 (2002) Solid mineral fuels-Determination of gross calorific value by the calorimetric method, and calculation of net calorific value.

33. PN-ISO 334 (1997) Solid mineral fuels-Determination of total sulphur-Eschka method.

34. PN-ISO 1171 (2002) Solid mineral fuels-Determination of ash.

35. PN-ISO 587 (2000) Solid mineral fuels-Determination of total chlorine using Eschka mixture.

36. Regulation of the Minister of Economy (2002) concerning other waste types than dangerous and types of installations and devices where their thermal transformation is allowed, Journal of Laws 02.18.176. 